\title{
Salinity Tolerance of Turf-type Tall Fescue as Affected by Nitrogen Sources
}

\author{
Zhao Xiang ${ }^{1}$ and Zhu Huisen ${ }^{1}$ \\ College of Animal Science and Veterinary Medicine, Shanxi Agricultural \\ University, Taigu, Shanxi 030801, China
}

Gao Yang and Li Deying²

Department of Plant Sciences, North Dakota State University, Fargo, ND 58108

Additional index words. cold, lawn, low temperature, salt, turfgrass

\begin{abstract}
Tall fescue [Schedonorus arundinaceus (Schreb) Dumort] has potential in cool arid regions, where it is often subject to salinity stress. The objective of this 2 -year field study was to investigate the effect of nitrogen sources on tall fescue turf quality under salinity stress in the northern Great Plains of North America. 'Wolfpack', 'Wolfpack II', 'Tar Heel', 'Tar Heel II', 'Jaguar 3', 'Jaguar 4G', and 'Arid 3' were treated with NaCl and $\mathrm{CaCl}_{2}$ in equal amounts. Six $\mathrm{N}$ sources were used for fertilization: nitrate-N, urea-N, ammonium-N, urea-N/ammonium-N/nitrate-N, urea-N with urase and nitrification inhibitor, and organic N. Salt treatment reduced turf quality of all cultivars. Turf quality was affected differently by $N$ source. Regardless of salt treatments, urea stabilized with a urease inhibitor and a nitrification inhibitor consistently had the best turf quality. Equal amounts of nitrate, ammonium, and urea-N yielded the lowest turf quality. However, there was no interaction between $N$ source and salt treatment. These results were also supported by green density (GD), dark-green color index (DGCI), shoot chlorophyll (Chl) content, and leaf relative water content (RWC). Tall fescue cultivars responded to salinity treatment differently, with 'Wolfpack II' being the cultivar ranked consistently at the top and maintained above the acceptable level of visual quality.
\end{abstract}

Turfgrass experiences salinity stress either because of salt-affected soils or because of salts from irrigation, especially from recycled water (Leskys et al., 1999). During the winter in cold regions, salts are often applied on roads to melt ice and snow for traffic safety. Most of the deicing salts move into adjacent lawns (Bryson and Barker, 2002). Excessive salts can cause nutrient imbalance or deficiency in turfgrasses, and some salts are toxic to plants (Bowman et al., 2006b; De Wit et al., 1963; Lacerda et al., 2003). Under severe salinity stress, turfgrasses show a lower density, poor vigor, and earlier senescence, with the ultimate result being poor visual and functional quality as a turf (Dean et al., 1996). In addition to using salt-tolerant species and cultivars, turfgrass managers have to adjust management practices, such as mowing, irrigation, and fertilization, as well as adopt other means to address salinity issues (Bowman et al., 2006a; Carrow and Duncan 1998).

Each management practice has a different impact on turfgrass under salinity stress. Increasing the mowing height can enhance salinity tolerance (Qian and Fu, 2005; Shahba, 2010). The benefit of increasing the mowing height is limited by the purpose of a mowed

Received for publication 24 Apr. 2018. Accepted for publication 24 June 2018.

${ }^{1}$ These authors contributed equally to this study. ${ }^{2}$ Corresponding author. E-mail: deying.li@ndsu. edu. turf that usually has a predetermined mowing height for optimal functionality. Increasing the irrigation amount to leach salts out of the root zones is a common practice in saltaffected turfgrass areas (Carrow and Duncan, 1998). The practicality of leaching is dependent on the type of salts, soil texture, water source, and the budget of management because leaching requires good-quality water, sufficient drainage, and repeated operations (Carrow and Duncan, 1998). Fertilization can also influence the salinity and $\mathrm{pH}$ of soils, depending on the forms of fertilizers and the time and rates of application (Carrow et al., 2001). Different fertilizers have different salt indices and contribute to various amounts of salts after they have gone through chemical and biologic reactions in soil following their application (Carrow et al., 2001).

Understanding the response of turfgrass cultivars to different fertilizers (especially different $\mathrm{N}$ sources) under salinity stress is very important for developing a sound management program. Although the ratio of two major sources of $\mathrm{N}\left(\mathrm{NH}_{4}^{+}\right.$to $\left.\mathrm{NO}_{3}{ }^{-}\right)$taken up by plants can affect growth and development, Agnew and Christians (1993) showed the effect was not significant for kentucky bluegrass (Poa pratensis L.) turf as long as the same amounts of water-soluble $\mathrm{N}$ are used. Interactions among cultivar, salinity, and fertilizer have been reported for many species and salt types (Brede and Bartell, 2009). For example, $\mathrm{N}$ source affected $\mathrm{Cl}^{-}$uptake in barley (Hordeum vulgare L.) (Britto et al., 2004), and $\mathrm{K}$ status in plants affected $\mathrm{Na}^{+}$ uptake in bermudagrass (Cynodon sp.) (Snyder and Cisar, 2005). Frechilla et al. (2001) reported that pea (Pisum sativum L.) plants were less sensitive to salinity when fertilized with nitrate than with ammonium. Similar results were reported for roses (Rosa hybrida) (Lorenzo et al., 2001) and wheat (Triticum aestivum L.) (Irshad et al., 2002). Ehlting et al. (2007) reported that gray poplar (Populus tremula $\times$ alba) performed better with nitrate than with ammonium fertilization under salinity stress. Indian mustard (Brassica juncea) grew better under nitrate than ammonium fertilization, but maximum growth happened with combinations of nitrate and ammoniacal $\mathrm{N}$ (Nathawat et al., 2007).

Tall fescue is a cool-season grass with moderate to high tolerance to salinity (Marcum, 2006). Tall fescue as turfgrass has improved substantially since the 1950s because of efforts in breeding for turf-type cultivars (Buckner et al., 1979). The use of this species as turfgrass has mainly been in the transitional arid zone of the United States. However, low-maintenance needs and the desire for drought and salinity tolerance extended the use of tall fescue farther north into cool, arid regions, especially where winter snow cover persists (Watkins et al., 2011). Limited information is available regarding the adaptation of different turf-type cultivars for use as mowed or unmowed turf areas in cool, arid regions where salinity tolerance is also desired. The primary objective of this study was to investigate the effect of $\mathrm{N}$ sources on turf quality of tall fescue managed under soil salinity stress.

\section{Materials and Methods}

Experimental setup. The experiments were conducted at the agricultural research station of North Dakota State University, Fargo, ND (lat. 46.8772E, long. 96.7898W). During the past 25 years, the monthly average low temperature was $-18.6{ }^{\circ} \mathrm{C}$, the monthly average high temperature was $27.8{ }^{\circ} \mathrm{C}$, and the average annual rain fall was $613 \mathrm{~mm}$ (485 $\mathrm{mm}$ rain from April to October, and $128 \mathrm{~mm}$ snow from November to March). Detailed weather data are available at the North Dakota Agricultural Weather Network (https://ndawn.ndsu.nodak.edu//). The soil was a Fargo-Ryan silty clay [(fine, montmorillonitic, frigid Vertic Haplaquall)-(fine, montmorillonitic, Typic Natraquoll)], with $3.8 \%$ organic matter and a soil particle size composition of $2 \%$ sand, $44 \%$ silt, and $54 \%$ clay. Soil $\mathrm{pH}$ was 7.6, and available $\mathrm{P}$ and $\mathrm{K}$ contents were 80 and $190 \mathrm{mg} \cdot \mathrm{kg}^{-1}$, respectively. A preliminary trial of turf-type tall fescue including 25 cultivars during 2003 to 2013 at this location showed that 'Wolfpack' and 'Jaguar 3' demonstrated acceptable winterhardiness. 'Wolfpack' and 'Tar Heel' were reported to have different salinity tolerances (Wipff and Rose-Fricker, 2003). Based on previous results and the availability of improved cultivars, tall fescue cultivars Wolfpack, Wolfpack II, Tar Heel, Tar Heel II, 
Jaguar 3, Jaguar 4G, and Arid 3 were chosen for the study and were seeded at $400 \mathrm{~kg} \cdot \mathrm{ha}^{-1}$ in Aug. 2014. Before seeding, an $18 \mathrm{~N}-10.5 \mathrm{P}-$ $10 \mathrm{~K}$ starter fertilizer was applied at an $\mathrm{N}$ rate of $50 \mathrm{~kg} \cdot \mathrm{ha}^{-1}$. Irrigation was applied when necessary to keep the soil moist during establishment with an automatic irrigation sprinkler system. The grass was fully established by Nov. 2014, when consistent snow cover started.

The experimental treatments started when the grass greened up in mid May 2015. The experiment was arranged in a split-split plot design with cultivar as the main plot, salinity as the subplot, and $\mathrm{N}$ source as the subsubplot. Three replications were included. The size of a sub-subplot was $3 \mathrm{~m}^{2}(1.5 \times$ $2 \mathrm{~m}$ ). In both 2015 and 2016, salts was applied with a 75 -cm-wide drop spreader in equal weight of $\mathrm{NaCl}$ and $\mathrm{CaCl}_{2}$ for a total amount of $1000 \mathrm{~kg} \cdot \mathrm{ha}^{-1}$ on 15 May to initiate soil salinity, resulting in an average soil electric conductivity (EC) of 0.85 $\mathrm{dS} \cdot \mathrm{m}^{-1} 1$ week after application at the $15-\mathrm{cm}$ depth of soil in the treated plots compared with $0.2 \mathrm{dS} \cdot \mathrm{m}^{-1}$ in the untreated plots. The mixture of $\mathrm{NaCl}$ and $\mathrm{CaCl}_{2}$ was used to focus on osmotic stress instead of ionic toxicity (Marcum, 2001). The salts were also applied at $100 \mathrm{~kg} \cdot \mathrm{ha}^{-1}$ in mid June, July, and August to supplement the loss from leaching, and resulted in a soil EC of 1.2 and $1.4 \mathrm{dS} \cdot \mathrm{m}^{-1}$ at the end of Oct. 2015 and 2016 , respectively.

Fertilization treatments included six $\mathrm{N}$ sources: 1) nitrate, 2) urea-N, 3) ammonium (containing 24\% S), 4) nitrate + urea + ammonium (containing 2.9\% urea-N, 3\% ammonium-N, $2.4 \%$ nitrate-N, and $3.74 \%$ S), 5) urea stabilized with urase inhibitor and nitrification inhibitor $\left(\mathrm{Umaxx}^{\circledR}, \quad\right.$ J.R. Simplot Co., Boise, ID), and 6) organic fertilizer $(5 \mathrm{~N}-0.9 \mathrm{P}-0 \mathrm{~K})$ (Milorganite ${ }^{\circledR}$, Milwaukee, WI). Fertilizers were applied based on an $\mathrm{N}$ rate of $25 \mathrm{~kg} \cdot \mathrm{ha}^{-1}$ per application. The frequent application of low rate was to avoid salinity effects of fertilizers. The differences in $\mathrm{K}$ and $\mathrm{S}$ fertilizers were made up with $\mathrm{KCl}$ and granular S. Fertilizers were applied monthly from May to September at the end of each month in 2015 and 2016 using a handheld spreader.

The grass was mowed at a $6.5-\mathrm{cm}$ height weekly during the growing season and was irrigated to replace evapotranspiration based on the reference evapotranspiration from a weather station located onsite and using a crop coefficient of 0.6 (Ervin and Koski, 1998).

Measurements and data collection. Soil $\mathrm{pH}$ and $\mathrm{EC}$ at the 15-cm depth were measured at the end of May and Oct. 2015 and 2016. The soil $\mathrm{pH}$ was tested in a 1:1 soil/deionized water (v/v) suspension using a multiparameter meter (HQ40d; Hach Company, Loveland, $\mathrm{CO}$ ), and EC was determined in a 1:5 soil/deionized water (v/v) extract using an EC meter (VWR Scientific, Radnor, PA).

Turf visual quality and digital image data were collected $1 \mathrm{~d}$ before the fertilization in June, July, Aug., Sept., and mid Oct. 2015 and 2016. Turf visual quality was evaluated using the 1 to 9 scale evaluation system (National Turfgrass Evaluation Program, http://www.ntep.org/), where 9 is the best, 6 is the minimum acceptable, and 1 is completely dead. For image analysis, digital images were taken from each plot under high-intensity halogen light using a Canon Power Shot G3 digital camera (Canon Inc.,
Tokyo, Japan) with settings of F2.0 and 1/60 s. The digital pictures were then analyzed using the software package NIH ImageJ $1.45 \mathrm{i}$ (National Institutes of Health, Bethesda, MD). The turfgrass DGCI and GD within the image were calculated following the methods of Karcher and Richardson (2003) and Richardson et al. (2001). The DGCI is a color index THAT combines hue, saturation, and brightness. The GD is the area percentage of green pixels in an area.

Leaf Chl content was measured in mid Oct. 2015 and 2016. About $0.03 \mathrm{~g}$ of each leaf sample was ground, weighed, and transferred to a centrifuge tube. To each sample, $2 \mathrm{~mL}$ $80 \%$ acetone was then added. The tubes were then capped and kept in darkness at $-4{ }^{\circ} \mathrm{C}$ overnight for extraction. The extract was centrifuged at $-4{ }^{\circ} \mathrm{C}$, and $50 \mu \mathrm{L}$ of the supernatant was diluted by adding $950 \mu \mathrm{L}$ $80 \%$ acetone. After thorough mixing, the absorbance of the diluted extraction was measured with a Beckman DU 640 spectrophotometer (Beckman Instruments Inc., Fullerton, CA) at wavelengths of $470,646.8$, and $663.2 \mathrm{~nm}$. The concentrations of $\mathrm{Chl}$ were determined following the equations by Lichtenthaler (1987).

Leaf RWC was measured in mid Oct. 2015 and 2016. About $2 \mathrm{~g}$ of leaf samples was weighed immediately to obtain the fresh weight (fw) and then submerged in distilled water for $6 \mathrm{~h}$. The soaked leaves were blotdried with paper towels before weighing again to obtain the turgid weight (sw). The final dry weight (dw) was obtained by weighing the leaves after drying in an oven at $68^{\circ} \mathrm{C}$ for $48 \mathrm{~h}$. Leaf RWC was calculated using the equation

Table 1. Visual quality of tall fescue turf as affected by salt, cultivar, and nitrogen (N) source during the 2015 and 2016 growing seasons.

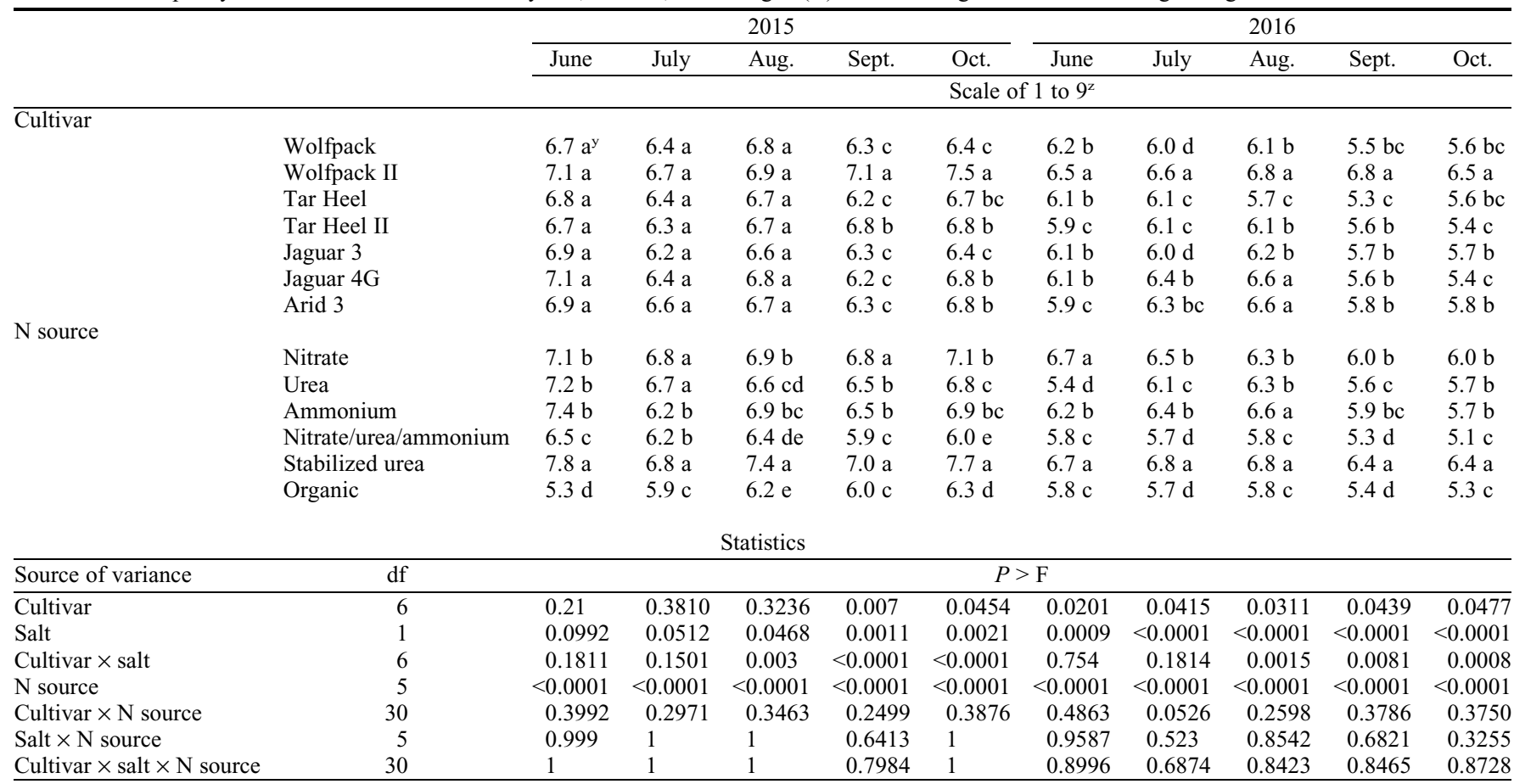

${ }^{\mathrm{z}}$ Turf visual quality was evaluated using a scale of 1 to 9 (National Turfgrass Evaluation Program, http://www.ntep.org/), where 9 is the best, 6 is the minimum acceptable, and 1 is completely dead turf.

${ }^{\mathrm{y}}$ Means followed by the same letter within a column are not significantly different at the $0.05 P$ level. 


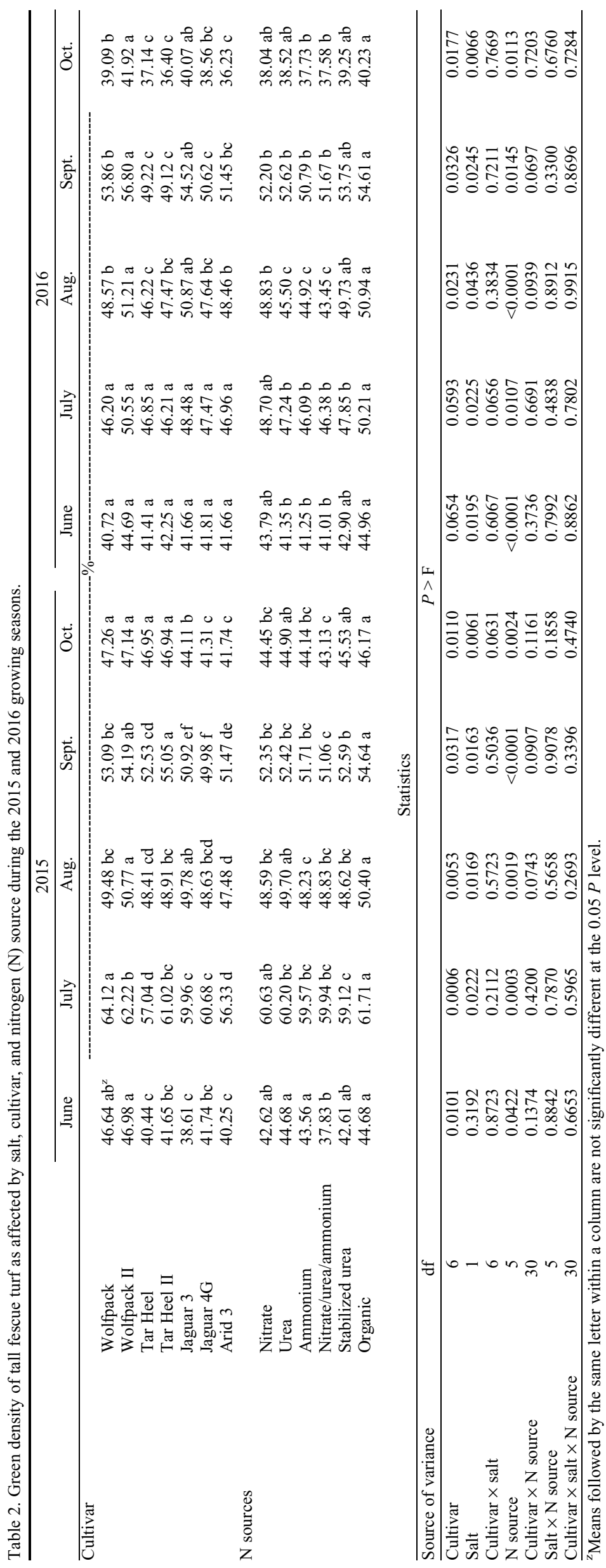

$$
\operatorname{RWC}(\%)=\frac{\mathrm{fw}-\mathrm{dw}}{\mathrm{sw}-\mathrm{dw}} .
$$

Statistical analysis. Data from the 2 years were not homogenous as determined by Hovest test. Therefore, the data of each year were subjected to analysis of variance separately using the Mixed procedure of SAS9.2 (SAS Institute, Cary, NC), with blocks treated as a random variable. Treatment means were separated using Fisher's protected least significant difference at the $0.05 P$ level.

\section{Results and Discussion}

Turf quality. Tall fescue cultivars showed different visual quality when evaluated in Sept. and Oct. 2015, and in all evaluations in 2016 (Table 1). 'Wolfpack II' ranked consistently at the top among seven cultivars and is the only cultivar that maintained a visual quality above the acceptable rating during all evaluations. Salt treatments reduced turf visual quality compared with the untreated control starting in Aug. 2015 and continuing through 2016. There was an interaction between cultivar and salts from August to October in both years, indicating that the cultivars responded differently to salt treatment (Table 1 ). $\mathrm{N}$ source resulted in different turf visual quality, with stabilized urea as the best, followed by nitrate$\mathrm{N}$. Stabilized urea and nitrate-N were the two N sources that resulted in an acceptable quality rating in all evaluations. There was no interaction between cultivar and $\mathrm{N}$ source or between salt and $\mathrm{N}$ source (Table 1).

Turf visual quality is a composite value reflecting evaluators' judgment of turfgrass density, color, vigor, weed status, and uniformity. The effects of salt on each component of visual quality may not be equal for different cultivars. Therefore, interpretation of the interaction between cultivars and salt needs further information about these quality components using separate evaluation or measurement.

Green density and color. Cultivars showed different GD throughout the study except for the June and July measurements in 2016 (Table 2). GD as one of the components of turf visual quality can be evaluated separately and more accurately using image analysis than visual scoring. As a result, the timing of cultivar difference detected was different based on GD compared with that based on visual scoring. As was the case of turf visual quality, GD was affected significantly by $\mathrm{N}$ source on all assessment dates (Table 2). However, there was no interaction between cultivars and $\mathrm{N}$ source.

Salt treatment lowered the GD of tall fescue turf compared with the control in 9 of 10 measurements. Salinity stress usually causes physiologic drought, which is more severe during hot, dry months. For example, Gao and Li (2014) found that salinity stress decreased the tiller appearance rate and leaf appearance rate significantly, which resulted in lower GD of tall fescue. Our results agreed with Gao and Li (2014) in the ranking of 'Wolfpack' better than 'Tar Heel II'. There was no interaction between cultivars and salt treatment, indicating that the cultivar ranking 
on GD was unaffected by salinity stress. The absence of an interaction between cultivars and salt treatment for GD differed from that for turf visual quality, indicating that the interaction effect on turf visual quality might not be a result of density but of other quality components, such as green color, which is affected by $\mathrm{Chl}$ and nutrient concentration.

Because the measurement of DGCI was based on artificial light, the color was unaffected by environmental conditions. The aspects of color in the red, green, and blue scheme described as DGCI is an objective indicator of greenness of the turfgrass canopy. Cultivar DGCI differences were found in Sept. and Oct. 2015 and from June to Oct. 2016. Salt treatment reduced DGCI on the same timeline as cultivar difference (Table 3 ). The cultivarby-salt interaction effect on DGCI was concurrent with that on visual quality, which was significant in 6 of 10 assessments (Table 3).

$\mathrm{N}$ source resulted in different DGCI in Sept. and Oct. 2015 and in June to Oct. 2016 (Table 3). Unlike GD, difference in DGCI occurred at the same time when difference of turf visual quality occurred. This concurrence suggests that color was more influential than density on visual evaluation of turf quality in this study. The Chl content provided more evidence of a greater contribution from color than from density to visual quality because Chl content showed cultivar-by-salt interactions in October measurements of both years (Table 4).

Relative water content. The levels of RWC indicate the water conservation capability

Table 3. Dark-green color index of tall fescue turf as affected by salt, cultivar, and nitrogen (N) source during the 2015 and 2016 growing seasons.

\begin{tabular}{|c|c|c|c|c|c|c|c|c|c|c|c|}
\hline & & \multicolumn{5}{|c|}{2015} & \multicolumn{5}{|c|}{2016} \\
\hline & & June & July & Aug. & Sept. & Oct. & June & July & Aug. & Sept. & Oct. \\
\hline & Wolfpack & $0.13 \mathrm{a}^{\mathrm{z}}$ & $0.13 \mathrm{a}$ & $0.21 \mathrm{a}$ & $0.22 \mathrm{~d}$ & $0.18 b$ & $0.18 \mathrm{ab}$ & $0.18 \mathrm{ab}$ & $0.20 \mathrm{c}$ & $0.20 \mathrm{a}$ & $0.23 \mathrm{~b}$ \\
\hline & Tar Heel II & $0.13 \mathrm{a}$ & $0.12 \mathrm{a}$ & $0.21 \mathrm{a}$ & $0.25 \mathrm{~b}$ & $0.19 \mathrm{a} b$ & $0.17 \mathrm{~b}$ & $0.18 \mathrm{ab}$ & $0.23 \mathrm{~b}$ & $0.20 \mathrm{a}$ & $0.23 \mathrm{~b}$ \\
\hline & Jaguar 3 & $0.13 \mathrm{a}$ & $0.13 \mathrm{a}$ & $0.22 \mathrm{a}$ & $0.19 \mathrm{e}$ & $0.17 \mathrm{c}$ & $0.15 b c$ & $0.16 \mathrm{~b}$ & $0.24 \mathrm{ab}$ & $0.21 \mathrm{a}$ & $0.22 \mathrm{bc}$ \\
\hline & Jaguar 4G & $0.14 \mathrm{a}$ & $0.13 \mathrm{a}$ & $0.21 \mathrm{a}$ & $0.21 \mathrm{~d}$ & $0.15 \mathrm{~d}$ & $0.14 \mathrm{c}$ & $0.17 \mathrm{~b}$ & $0.24 \mathrm{ab}$ & $0.20 \mathrm{a}$ & $0.23 \mathrm{~b}$ \\
\hline & Urea & $0.13 \mathrm{a}$ & $0.13 \mathrm{a}$ & $0.22 \mathrm{a}$ & $0.25 \mathrm{~b}$ & $0.19 \mathrm{~b}$ & $0.18 \mathrm{~b}$ & $0.16 \mathrm{bc}$ & $0.24 \mathrm{~b}$ & $0.21 \mathrm{~b}$ & $0.25 \mathrm{~b}$ \\
\hline & Ammonium & $0.14 \mathrm{a}$ & $0.14 \mathrm{a}$ & $0.22 \mathrm{a}$ & $0.22 \mathrm{c}$ & $0.17 \mathrm{c}$ & $0.17 \mathrm{bc}$ & $0.16 \mathrm{bc}$ & $0.23 \mathrm{bc}$ & $0.21 \mathrm{~b}$ & $0.23 \mathrm{c}$ \\
\hline & Nitrate/urea/ammonium & $0.12 \mathrm{a}$ & $0.13 \mathrm{a}$ & $0.21 \mathrm{a}$ & $0.22 \mathrm{c}$ & $0.16 \mathrm{c}$ & $0.17 \mathrm{bc}$ & $0.15 \mathrm{c}$ & $0.21 \mathrm{bc}$ & $0.19 \mathrm{~d}$ & $0.22 \mathrm{c}$ \\
\hline & Stabilized urea & $0.15 \mathrm{a}$ & $0.15 \mathrm{a}$ & $0.22 \mathrm{a}$ & $0.27 \mathrm{a}$ & $0.23 \mathrm{a}$ & $0.21 \mathrm{a}$ & $0.20 \mathrm{a}$ & $0.28 \mathrm{a}$ & $0.22 \mathrm{a}$ & $0.27 \mathrm{a}$ \\
\hline & Organic & $0.12 \mathrm{a}$ & $0.13 \mathrm{a}$ & $0.22 \mathrm{a}$ & $0.23 \mathrm{c}$ & $0.16 \mathrm{c}$ & $0.15 \mathrm{c}$ & $0.15 \mathrm{c}$ & $0.20 \mathrm{c}$ & $0.20 \mathrm{c}$ & $0.22 \mathrm{c}$ \\
\hline Cultivar $\times$ salt & 6 & 0.1055 & 0.2551 & 0.0409 & 0.0285 & 0.0260 & 0.5877 & 0.5346 & 0.0996 & 0.0213 & 0.0444 \\
\hline $\mathrm{N}$ source & 5 & 0.1650 & 0.1001 & 0.0818 & $<0.0001$ & $<0.0001$ & 0.0023 & $<0.0001$ & $<0.0001$ & $<0.0001$ & $<0.0001$ \\
\hline Cultivar $\times \mathrm{N}$ source & 30 & 0.3748 & 0.5795 & 0.7453 & 0.7758 & 0.2890 & 0.6012 & 0.0550 & 0.2527 & 0.5711 & 0.4763 \\
\hline Salt $\times$ N source & 5 & 0.5614 & 0.6749 & 0.6370 & 0.7807 & 0.5865 & 0.9432 & 0.3933 & 0.6948 & 0.5009 & 0.7839 \\
\hline Cultivar $\times$ salt $\times N$ source & 30 & 0.8846 & 0.7269 & 0.9000 & 0.4728 & 0.8829 & 0.9086 & 0.7924 & 0.9956 & 0.7125 & 0.9715 \\
\hline
\end{tabular}

${ }^{\mathrm{z}}$ Means followed by same letter within a column are not significantly different at the $0.05 P$ level.

Table 4. Chlorophyll (Chl) content and relative water content (RWC) of tall fescue leaves as affected by salt, cultivar, and nitrogen (N) source in October of 2015 and 2016.

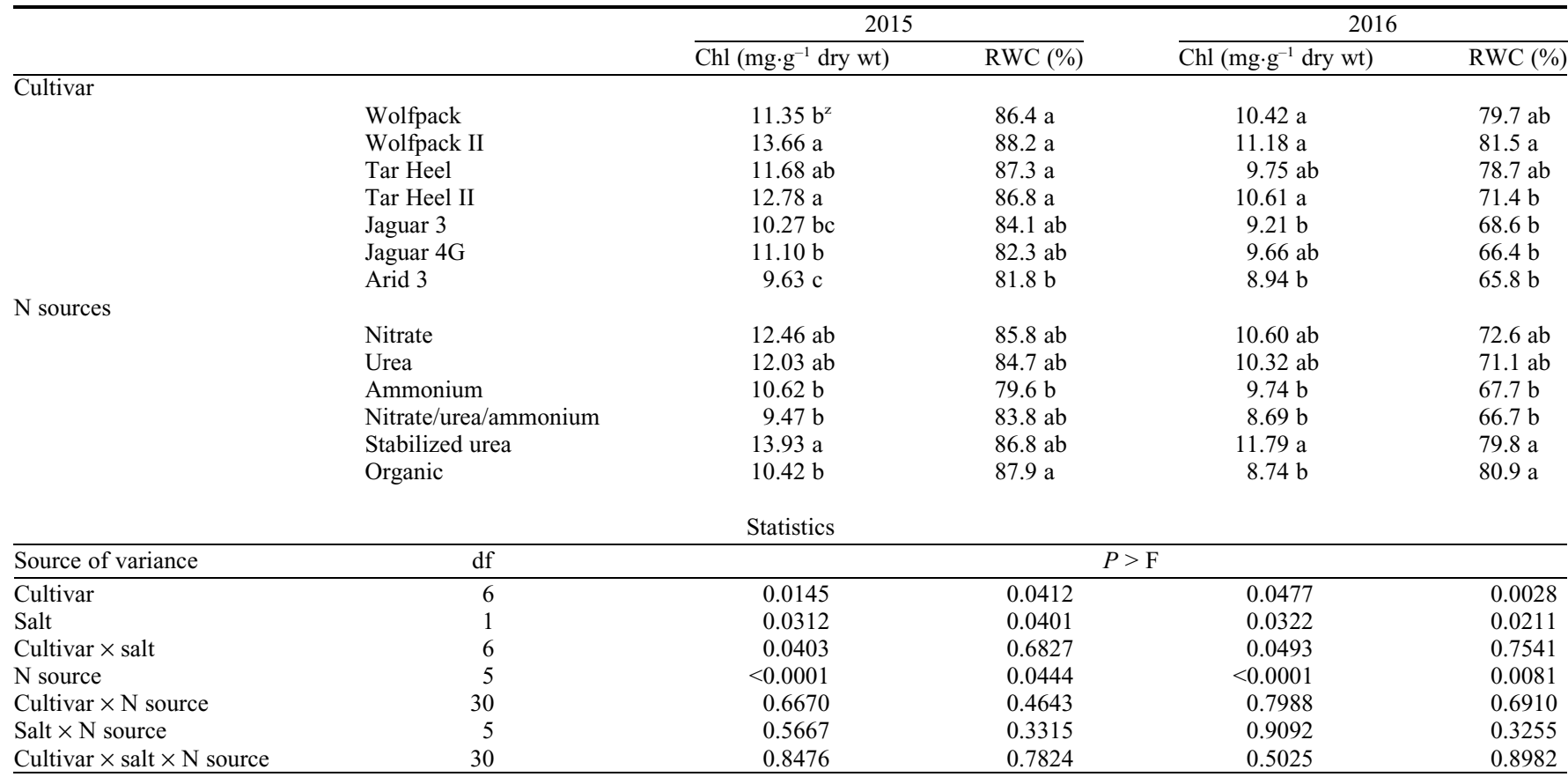

${ }^{\mathrm{z}}$ Means followed by the same letter within a column are not significantly different at the $0.05 P$ level. 
of plant leaves, which are very sensitive to water stress (Gao and Li 2012). In this study, cultivars showed different RWC values, indicating these cultivars had different sensitivity to stress (Table 4). We found that 'Wolfpack II' consistently had the highest RWC, whereas 'Arid 3' had the lowest across the different $\mathrm{N}$ sources. N source affected RWC significantly without interaction with the cultivars. Salinity stress resulted in lower RWC values in all tall fescue cultivars. Changes in stomatal conductance, leaf water potential, green tissue density, and electrolyte leakage have been reported as common physiologic responses to salinity stress in turfgrasses (Bushman et al., 2016; Friell et al., 2013; Koch et al., 2011; Xiang et al., 2017). Also, because there was no interaction among cultivars, salt treatment, and $\mathrm{N}$ source (Table 4), the results of salt treatment across $\mathrm{N}$ sources and cultivars are not included or discussed.

\section{Conclusion}

Cultivars tested in this study showed different visual quality, which was affected by salt treatment and N source. 'Wolfpack II' showed the highest quality with or without salt treatment. The $\mathrm{N}$ source resulted in different turf quality from the seven cultivars with or without salt treatment. Urea stabilized with urease inhibitor and nitrification inhibitor resulted consistently in better turf quality. Equal amounts of nitrate, ammonium, and urea-N presented the lowest turf quality. The lack of interactions between cultivar and $\mathrm{N}$ source on the turf quality suggests that recommendation of cultivars is unaffected by $\mathrm{N}$ fertilization programs.

\section{Literature Cited}

Agnew, M.L. and N.E. Christians. 1993. Influence of fertilizer source and core cultivation on the growth of Kentucky bluegrass. Intl. Turfgrass Soc. Res. J. 7:458-463.

Bowman, D.C., G.R. Cramer, and D.A. Devitt. 2006a. Effect of nitrogen status on salinity tolerance of tall fescue turf. J. Plant Nutr. 29:1491-1497.

Bowman, D.C., G.R. Cramer, and D.A. Devitt. 2006b. Effect of salinity and nitrogen status on nitrogen uptake by tall fescue turf. J. Plant Nutr. 29:1481-1490.

Brede, A.D. and E. Bartell. 2009. Cultivar X fertilizer interaction in Kentucky bluegrass and perennial ryegrass turf. Intl. Turfgrass Soc. Res. J. 11:967-977.

Britto, D.T., T.J. Ruth, S. Lapi, and H.J. Kronzucker. 2004. Cellular and whole-plant chloride dynamics in barley: Insights into chloride-nitrogen interactions and salinity responses. Planta 218:615-622.

Bryson, G.M. and A.V. Barker. 2002. Sodium accumulation in soils and plants along Massachusetts roadsides. Commun. Soil Sci. Plant Anal. 33:67-78.

Buckner, R.C., J.B. Powell, and R.V. Frakes. 1979. Historical development, p. 1-8. In: R.C. Buckner and L.P. Bush (eds): Tall fescue Agron. Monogr. 20. ASA, CSSA, and SSSA, Madison, WI.

Bushman, B.S., L. Wang, X. Dai, A. Joshi, J.G. Robins, and P.G. Johnson. 2016. Responses of tolerant and susceptible kentucky bluegrass germplasm to salt stress. J. Amer. Soc. Hort. Sci. 141:449-456.

Carrow, R.N. and R.R. Duncan. 1998. Salt-affected turfgrass sites: Assessment and management. Sleeping Bear Press, Inc., Chelsea, MI.

Carrow, R.N., D.V. Waddington, and R.E. Rieke. 2001. Turfgrass soil fertility and chemical problems: Assessment and management. Sleeping Bear Press, Inc., Chelsea, MI.

De Wit, C.R., W. Dijkshoorn, and J.C. Noggle. 1963. Ionic balance and growth of plants. Versl. Landbouwk. Onderz NR.69.15:168.

Dean, D.E., D.A. Devitt, L.S. Verchick, and R.L. Morris. 1996. Turfgrass quality, growth, and water use influenced by salinity and water stress. Agron. J. 88:844-849.

Ehlting, B., P. Dluzniewska, H. Dietrich, A. Selle, M. Teuber, R. Hansch, U. Nehls, A. Polle, J.P. Schnitzler, H. Rennenberg, and A. Gessler. 2007. Interaction of nitrogen nutrition and salinity in Grey poplar (Populus tremula $\times$ alba). Plant Cell Environ. 30:796-811.

Ervin, E.H. and A.J. Koski. 1998. Drought avoidance aspects and crop coefficients of Kentucky bluegrass and tall fescue turfs in the semiarid west. Crop Sci. 38:788-795.

Frechilla, S., B. Lasa, L. Ibarretxe, C. Lamsfus, and P. Aparicio-Tejo. 2001. Pea responses to saline stress is affected by the source of nitrogen nutrition (ammonium or nitrate). Plant Growth Regulat. 35:171-179.

Friell, J., E. Watkins, and B. Horgan. 2013. Salinity tolerance of 74 turfgrass cultivars in nutrient solution culture. Crop Sci. 53:17431749.

Gao, Y. and D. Li. 2012. Detecting salinity stress in tall fescue based on single leaf spectrum. Scientia Hort. 138:159-164.

Gao, Y. and D. Li. 2014. Growth responses of tall fescue (Festuca arundinacea Schreb.) to salinity stress. Eur. J. Hort. Sci. 79:123128.

Irshad, M., T. Honna, A.E. Eneji, and S. Yamamoto. 2002. Wheat response to nitrogen source under saline conditions. J. Plant Nutr. 25:2603-2612.

Karcher, E.E. and M.D. Richardson. 2003. Quantifying turfgrass color using digital image analysis. Crop Sci. 43:943-951.
Koch, M.J., B. Huang, and S.A. Bonos. 2011. Salinity tolerance of kentucky bluegrass cultivars and selections using an overhead irrigated screening technique. Crop Sci. 51:2846-2857.

Lacerda, C.F., J. Cambraia, M.A. Oliva, H.A. Ruiz, and J.T. Prisco. 2003. Solute accumulation and distribution during shoot and leaf development in two sorghum genotypes under salt stress. Environ. Exp. Bot. 49:107-120.

Leskys, A.M., D.A. Devitt, R.L. Morris, and L.S. Verchick. 1999. Response of tall fescue to saline water as influenced by leaching fractions and irrigation uniformity distributions. Agron. J. 91:409-416.

Lichtenthaler, H.K. 1987. Chlorophyll and carotenoids: Pigments of photosynthetic biomembranes. Methods Enzymol. 148:331-382.

Lorenzo, H., J.M. Siverio, and M. Caballero. 2001. Salinity and nitrogen fertilization and nitrogen metabolism in rose plants. J. Agr. Sci 137:7784.

Marcum, K.B. 2001. Salinity tolerance of 35 bentgrass cultivars. HortScience 36:374-376.

Marcum, K.B. 2006. Use of saline and non-potable water in the turfgrass industry: Constraints and developments. Agr. Water Mgt. 80:132-146.

Nathawat, N.S., M.S. Kuhad, C.L. Goswami, A.L. Patel, and R. Kumar. 2007. Interactive effects of nitrogen source and salinity on growth indices and ion content of Indian mustard. J. Plant Nutr. 30:569-598.

Qian, Y.L. and J.M. Fu. 2005. Response of creeping bentgrass to salinity and mowing management: Carbohydrate availability and ion accumulation. HortScience 40:21702174.

Richardson, M.D., E.E. Karcher, and L.C. Purcell. 2001. Quantifying turfgrass cover using digital image analysis. Crop Sci. 41:1884-1888.

Shahba, M.A. 2010. Interaction effects of salinity and mowing on performance and physiology of bermudagrass cultivars. Crop Sci. 50:26202631.

Snyder, G.H. and J. Cisar. 2005. Potassium fertilization responses as affected by sodium. Intl. Turfgrass Soc. Res. J. 10:428-435.

Watkins, E., S. Fei, D. Gardner, J. Stier, S. Bughrara, D. Li, C. Bigelow, L. Schleicher, B. Horgan, and K. Diesburg. 2011. Low-input turfgrass species for the north central United States. Appl. Turfgrass Sci., doi: 10.1094/ATS2011-0126-02-RS.

Wipff, J.K. and C.A. Rose-Fricker. 2003. Salt tolerance comparisons among tall fescue cultivars. In: 2003 Annu. Meet. Abstr., ASA/CSSSA/SSSA, Denver, Co. 2-6 Nov. 2003. ASA/CSSA/SSSA, Madison, WI.

Xiang, M., J.Q. Moss, D.L. Martin, K. Su, and B.L. Dunn. 2017. Evaluating the salinity tolerance of clonal-type bermudagrass cultivars and an experimental selection. HortScience 52:185-191. 